\title{
Axelheibergella (Ostracoda, Crustacea), a new genus of marginally septate cladocopid ostracods from the central Arctic Ocean
}

\author{
WILLIAM M. BRIGGS, Jr
}

Institute of Arctic and Alpine Research (INSTAAR), University of Colorado, Campus Box 450, Boulder, CO 80309-0450, USA.

\begin{abstract}
The genus Axelheibergella is established for cladocopid ostracods with well-developed, radially aligned septa between the outer lamella and the relatively wide, free-margin infold parts of the shell. Two deep-water species of the genus are described from the Holocene of the Alpha Ridge rise and Axel Heiberg slope, central Arctic Ocean (CAO). Two other species are present in the warmer, shallower waters of the Mediterranean region. Presumably the septa are designed to strengthen the free margin of the shell. The relationship of the camerae (interseptal chambers) to marginal pore canals in extant ostracods, including the Punciacopina, and to the marginal shell glands of cladocopids and halocypridid myodocopids is discussed. Cladocopid and podocopid (podocopine) shell ultrastructure is discussed, and new terms are defined. The septate frill and its function in the enigmatic Punciacopina are discussed in the light of recent discoveries of the radically different lifestyle of Manawa, and presumably of Puncia and Promanawa, from other non-punciacean ostracods. It is suggested that the frill of the Punciacopina is homologous to the ala of some cytheracean (cytherurid) podocopid ostracods. Two unnamed species of Puncia from the New Zealand Pleistocene are illustrated, and complement the discussion of septa and camerae in Axelheibergella. J. Micropalaeontol. 16(2): 109-120, October 1997.
\end{abstract}

\section{INTRODUCTION}

This study is based on an examination of the ostracods present in the top 0-1 cm section of two bottom sediment samples from the central Arctic Ocean CAO (Fig. 1), one from the Alpha Ridge (CESAR 83-211, at a present-day water depth (PDWD) of $1730 \mathrm{~m})$ and the other from the continental margin off Axel Heiberg Island (AH 87200-009, $1150 \mathrm{~m}$ PDWD).

The two samples were collected by personnel of the Geological Survey of Canada from drifting ice islands during project CESAR over the Alpha Ridge (Jackson \& Mudie, 1984; Jackson et al., 1985), and during the Canadian Ice Island Project ISIS along the margin of the Canada Basin off Axel Heiberg Island (Mungall, 1984; Jackson, 1986). Each $0-1 \mathrm{~cm}$ sample contained specimens of two new species of a new genus of cladocopid ostracod characterized by well-developed, radially aligned septa between the outer lamella of the shell and the infold along the free margin of the shell. Table 1 lists the podocopid and cladocopid ostracod taxa present in the two samples.

The new genus Axelheibergella is established to accommodate cladocopid ostracods with marginally septate shells.

Although Axelheibergella is rare in bottom-surface samples from the two CESAR and Axel Heiberg sites discussed here (Fig. 1 and Table 1), an ongoing investigation by the present author and T. M. Cronin of core top and downcore samples from 18 box cores collected from the Arctic Ocean by the joint Canada-United States Expedition to the Arctic Ocean, 1994, and referred to as the Arctic Ocean Section 1994 (AOS'94), has produced 3048 specimens of $A$. arctica (2030) and A. punctata (1018) from eight of the box cores. The eight AOS'94 box cores containing ostracod assemblages that include the two species of Axelheibergella are from deep-water (1020-2400 m PDWD) ridge and slope sites in the Amerasian Basin (= Canada and Makarov Basins; Fig. 1) of the Arctic Ocean.

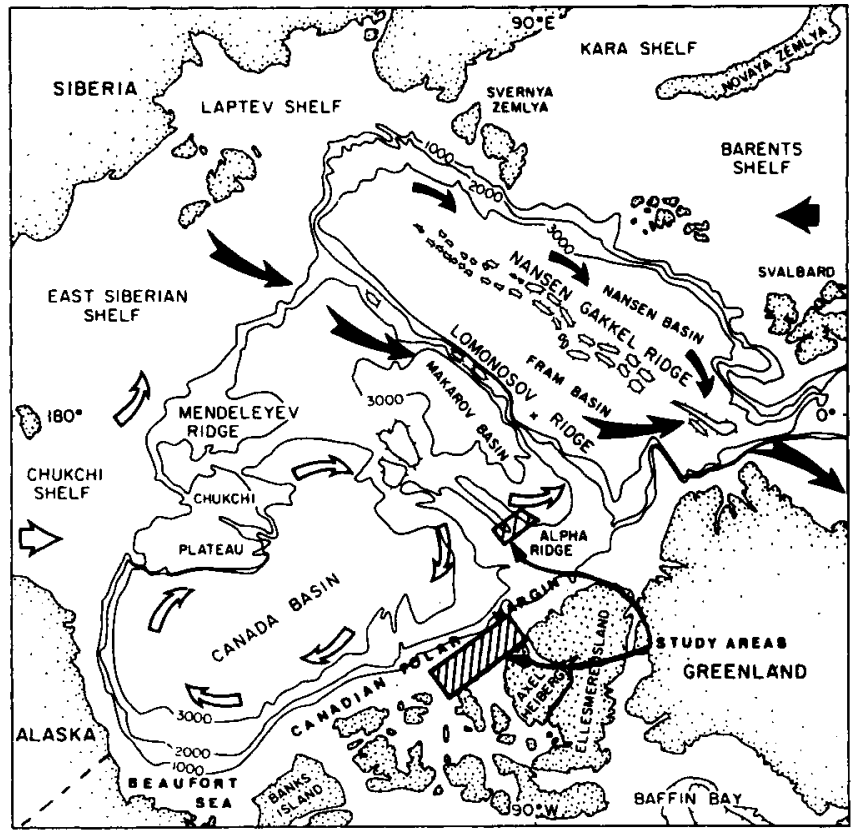

Fig. 1. Locality map of Arctic Ocean showing the two study areas, bathymetry, physiography and surface currents. Large clear and black arrows denote input of North Pacific and North Atlantic water, respectively; small clear arrows denote Beaufort Gyre; large black fishtail arrows denote Transpolar Drift (TPD) and export of water via Fram Strait, and smaller black arrows denote Siberian branch of TPD.

The presence of Axelheibergella in the Arctic Ocean and the Mediterranean Sea is one more piece of evidence linking the cladocopid and podocopid ostracods of these two widely separated regions (Cronin et al., 1994, 1995). 


\section{4}

4
1
13

13

1
50

Cytheropteron hamatum Sars, 1869

Cytheropteron ex gr. hamatum Sars, 1869

Cytheropteron porterae Whatley \& Coles, 1987

Cytheropteron pseudoinflatum Whatley \& Eynon, 1996

Cytheropteron scoresbyi Whatley \& Eynon, 1996

Cytheropteron testudo Sars, 1869

Eucytherura sp.

Henryhowella dasyderma (Brady, 1880)

Krithe glacialis Brady, Crosskey \& Robertson, 1874

Microcythere medistriata (Joy \& Clark, 1977)

Microcythere sp.

Paracytherois chukchiensis Joy \& Clark, 1977

Pedicythere neofluitans Joy \& Clark, 1977

Propontocypris sp.

Pseudocythere caudata Sars, 1866

Sclerochilus sp.

Swainocythere nanseni (Joy \& Clark, 1981)

Number of species

Number of specimens

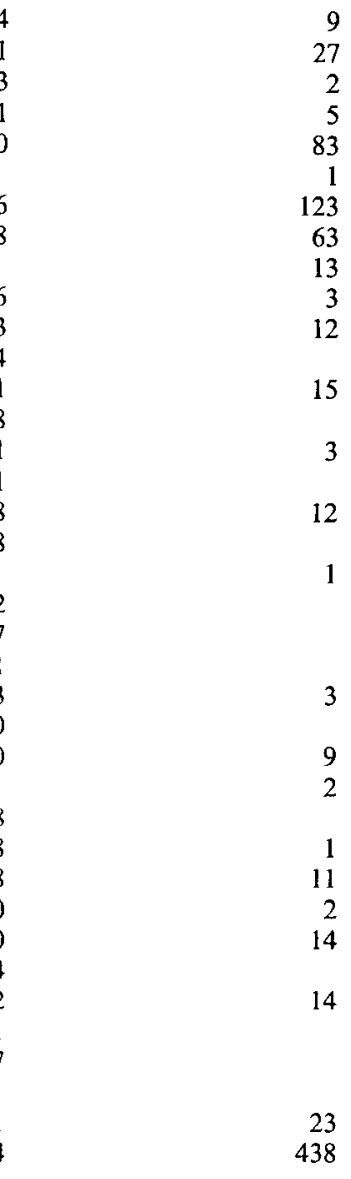

Table 1. Counts of cladocopid and podocopid ostracod species from CESAR and Axel Heiberg sites.

\section{PREVIOUS WORK}

Previous detailed work on the taxonomy and distribution of the modern ostracods of the CAO is limited to a single study by Joy \& Clark (1977). This study was based on an examination of the $0-3 \mathrm{~cm}$ section of the tops of gravity cores retrieved in water depths of 13513812 m from the Alpha Cordillera, Charlie Gap, Chukchi Rise and the Canada Basin, following the drift tract of Ice Island T-3 (Fletcher's Ice Island), which served as a platform for sample retrieval. Joy \& Clark (1977) identified eight species of cladocopids assignable to Polycope (Family Polycopidae), representing $42 \%$ of the total fauna of 19 species recorded from 33 core tops in their study area. None of the species of cladocopids identified by Joy \& Clark (1977) contain septa. More recently, some of the ostracod taxa dealt with by Joy \& Clark (1977) have been recorded from the Pleistocene sections of cores retrieved from the CAO (Clark et al., 1990; Pak et al., 1992). Additional studies by Cronin et al. (1994, 1995), and another by Briggs \& Mudie (in preparation), on the late Quaternary ostracods of the Arctic Ocean, emphasize the use of ostracods as proxy indicators of Arctic Ocean palaeoceanographic and palaeoclimatic history. Several intermediate-depth to deeper-water ostracod species that are common in the assemblages of the Amerasian and Eurasian Basins have been described as new by Whatley \& Eynon (1996) from deep-water sites in the Greenland Sea area of the North Atlantic Ocean. Two of these taxa are present in assemblages containing Axelheibergella from the CESAR and Axel Heiberg sites (Table 1).

\section{ENVIRONMENTAL SETTING \\ Water masses}

The three-layered division of the water masses in the CAO based on temperature and salinity consists of (1) Arctic surface water (ASW) (surface to $200 \mathrm{~m}$ ): cold, low salinity water; (2) Arctic intermediate water $(\mathrm{AIW})=$ Atlantic layer $(200-900 \mathrm{~m})$ : relatively warm $>0^{\circ} \mathrm{C}$, high salinity water; and (3) (ABW) Arctic bottom water $(>900 \mathrm{~m}):<0^{\circ} \mathrm{C}$, high salinity water (Coachman \& Aagaard, 1974). Aagaard et al. (1985) place the lower boundary of AIW in the Canada Basin at c. $1300 \mathrm{~m}$, and refer to the ABW in this area of the CAO as Canada Basin Deep Water (CBDW). 
The CESAR site at a depth of $1730 \mathrm{~m}$ is within the upper part of the CBDW, with bottom temperatures and salinities around $-0.5^{\circ} \mathrm{C}$ and $34.9 \%$ respectively. The Axel Heiberg slope site at a depth of $1150 \mathrm{~m}$ may lie within the uppermost part of CBDW, but the presence of Cytheropteron porterae, C. pseudoinflatum and C. testudo (Table 1) suggests lowermost AIW. Briggs \& Mudie (in preparation) present evidence that suggests the AIW/ CBDW boundary could be as deep as $c .1200-1300 \mathrm{~m}$, based on a semi-quantitative analysis of ostracod assemblages from CESAR and Axel Heiberg shelf/slope sites.

\section{Sedimentation rates}

Sedimentation rates in the nearly perennial ice-covered CAO during the latest Pleistocene-Holocene are on the order of $1-3 \mathrm{~mm} \mathrm{ka}^{-1}$ and are based on magneto-stratigraphic, accelerator mass spectrometry ${ }^{14} \mathrm{C}$ dating (to the limit of the method), and stable isotope studies (Clark et al., 1980, 1986; Witte \& Kent, 1988; Morris, 1988). Aksu (1985), Aksu \& Mudie (1985) and Scott et al. (1989) determined sedimentation rates of about $1 \mathrm{~mm} \mathrm{ka}^{-1}$ (maximum $1.5-3 \mathrm{~mm} \mathrm{ka}^{-1}$ ) in CESAR cores from the Alpha Ridge, and Van Wagoner et al. (1989) have suggested an accumulation rate of $0.8-3.9 \mathrm{~cm} \mathrm{ka}^{-1}$ on the Axel Heiberg shelf.

\section{Age of the ostracod fauna}

Because sedimentation rates are low in the CAO, some of the specimens of the two species on which Axelheibergella is based from the Axel Heiberg and CESAR sites may date from $1 \mathrm{ka}$ BP and the earliest Holocene, respectively. Unfortunately, the two $0-1 \mathrm{~cm}$ surface samples were not treated with a protoplasmspecific stain. Most of the 1252 specimens listed in Table 1 from the two sites are disarticulated valves and none contain appendages. Some support for the relict nature of the ostracod fauna comes from studies of the benthic foraminifera in surface sediments on the Axel Heiberg Shelf by Schröder-Adams et al. (1990a, b). Rose Bengal staining revealed that living specimens of foraminifera make up less than $3 \%$ of the surface population, suggesting that the surface fauna is largely subfossil or residual. The same may be true of the ostracods.

\section{MATERIAL AND METHODS}

The Arctic Ocean bottom sediments (Fig. 1) were collected by sampling devices lowered to the ocean floor through holes that penetrated the thickness of the ice islands. CESAR 83-211 is the $0-1 \mathrm{~cm}$ section from the top of a $46 \mathrm{~cm}$-long Benthos gravity core retrieved from the Alpha Ridge graben, $1730 \mathrm{~m}$ PDWD, at $85^{\circ} 43.9^{\prime} \mathrm{N}, 108^{\circ} 51.9^{\prime} \mathrm{W}$. (Jackson et al., 1985). Axel Heiberg AH $87200-009$ is the $0-1 \mathrm{~cm}$ section from the top surface of sediment retrieved by a Dietz-LaFond grab from the upper slope, $1150 \mathrm{~m}$ PDWD, at $82^{\circ} 09.62^{\prime} \mathrm{N}, 102^{\circ} 33.87^{\prime} \mathrm{W}$. For each of the samples used for microfossil analysis, about $35 \mathrm{ml}$ of wet sediment were processed and washed on a $63 \mu \mathrm{m}$ screen by personnel from the Bedford Institute of Oceanography.

The two illustrated species of Puncia are from samples collected at an exposure of Shakespeare Cliff Siltstone and Tainui Shellbed, Castlecliff coastal section, Wanganui Basin, North Island, New Zealand, which the author collected on 12 November 1965, with Alan Beu and Philip Maxwell, and which I subsequently recollected on 25 September 1970. The 1965 samples of Shakespeare Cliff Siltstone and Tainui Shellbed are recorded as NZMS 260 Sheet and Metric Fossil Record File No. R22/f6627 and R22/f6628, respectively. The 1970 recollections from these two units bear the same fossil record file numbers as the 1965 collections. Shakespeare Cliff Siltstone lies immediately above Tainui Shellbed stratigraphically, and both units lie within oxygen isotope stage 11 (Beu \& Edwards, 1984; Beu et al., 1987).

Reflected light photography of the holotype specimen (Pl. 1, fig. 1) of Axelheibergella arctica utilized a $16 \mathrm{~mm}$ Zeiss Luminar lens with the aperture set at $\mathrm{f} 15$, and a bellows draw that resulted in an initial magnification on the film of $40 \times$. The light source used was electronic flash from a single unit in the upper left field of view. The $35 \mathrm{~mm}$ camera shutter was locked open and the electronic flash was triggered manually by electric cable twice to produce the best image density on Kodak TMAX 100 photographic film. The transparent specimen was photographed in a single-cell microfaunal slide against the black background of the slide, which resulted in maximum contrast between shell structures and background. Transmitted light photography of specimens (Fig. 2, figs 1-3) of Axelheibergella utilized either an Olympus Vanox compound microscope with automatic exposure features or a Leitz compound microscope with a manual exposure meter, using Kodak Technical Pan film and tungsten light source. The specimens were photographed in a single-cavity glass slide using immersion oil with an RI of 1.5. Both types of film were developed for an exposure index (ASA/ISO) of 50/18 . The transmitted light photograph of Puncia sp. B (Fig. 2, fig. 4) was taken in late 1968 at Victoria University of Wellington, using a Leitz compound microscope, tungsten light source and green Wratten filter, with the specimen in the same type of glass cavity slide and immersed in clove oil, and using Kodak (Microfile) High Contrast Copy film. The film, which is no longer manufactured, was exposed and processed in such a way in Kodak Microdol-X developer that the ASA value of 64 was reduced to an approximate effective value of ASA 6.

Specimens selected for SEM photography were mounted on two stubs following the method described by Finch (1974). Given the rarity, small size and the fragility of the specimens, it was decided not to remove the paratype (Pl. 1, fig. 2) of Axelheibergella arctica, or the holotype (Pl. 1, fig. 6) and shell fragment (Pl. 1, fig. 12) of Axelheibergella punctata from the SEM stubs. Figured and unfigured specimens of both species of Axelheibergella are deposited in the Specimen Repository at the Geological Survey of Canada, Ottawa, Ontario, Canada. Specimens are referred to by a GSC (Geological Survey of Canada) catalogue number in the main body of text and in the plate and text-figure explanations for illustrated specimens. Specimens of the two species of Puncia are deposited in the ostracod collections of the Institute of Geological \& Nuclear Sciences (IGNS), Ltd. (formerly the New Zealand Geological Survey), Lower Hutt, New Zealand, and are referred to by IGNS preceding their catalogue numbers.

The shell terminology used follows closely that proposed by Kornicker (1969). Axial zone as used in this report refers to the area of the shell between outer lamella and infold, including the vestibule; it is delimited distally by the edge of the shell and proximally by the inner margin of the infold. Kornicker's (1969) use of the term excluded the vestibule. Although a rostrum is not 

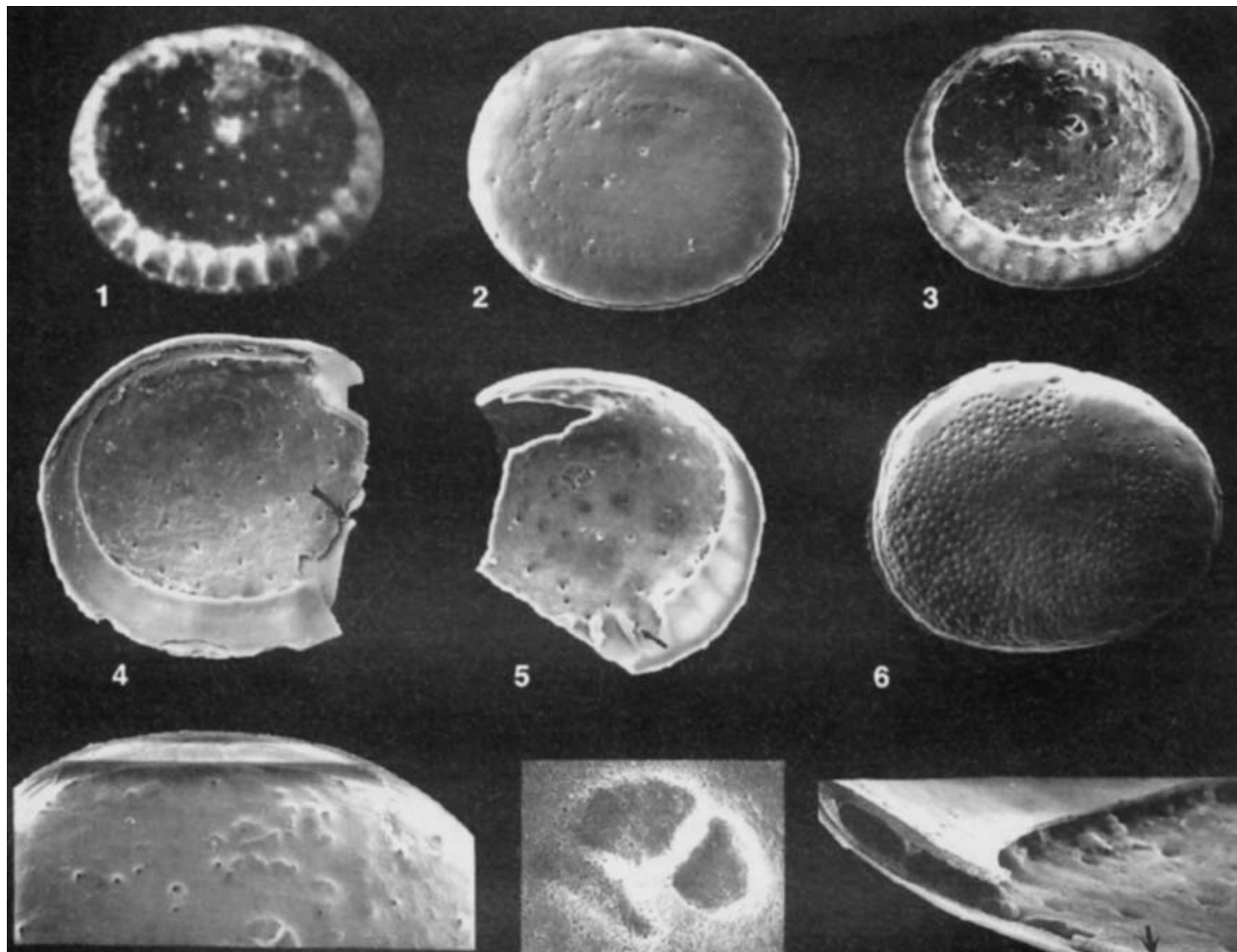

7

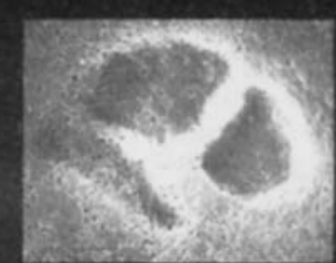

8

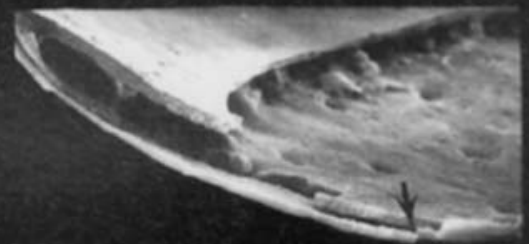

9

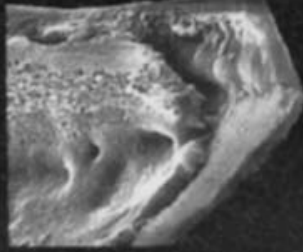

10

11

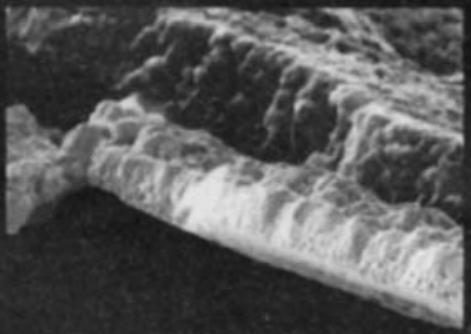

12
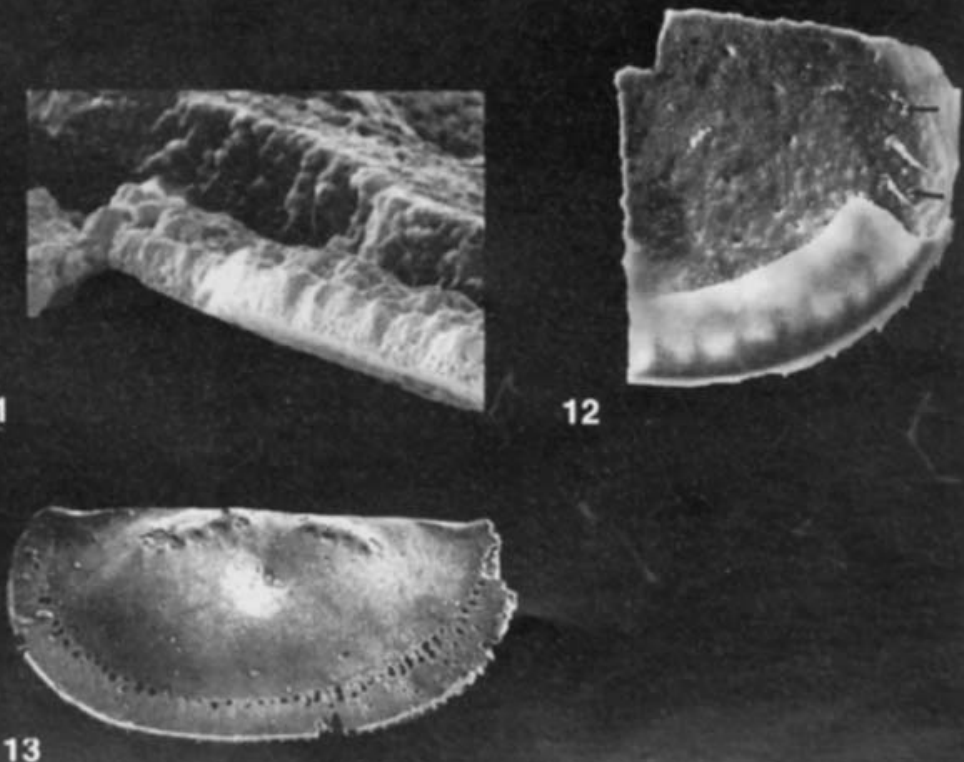

Plate 1 


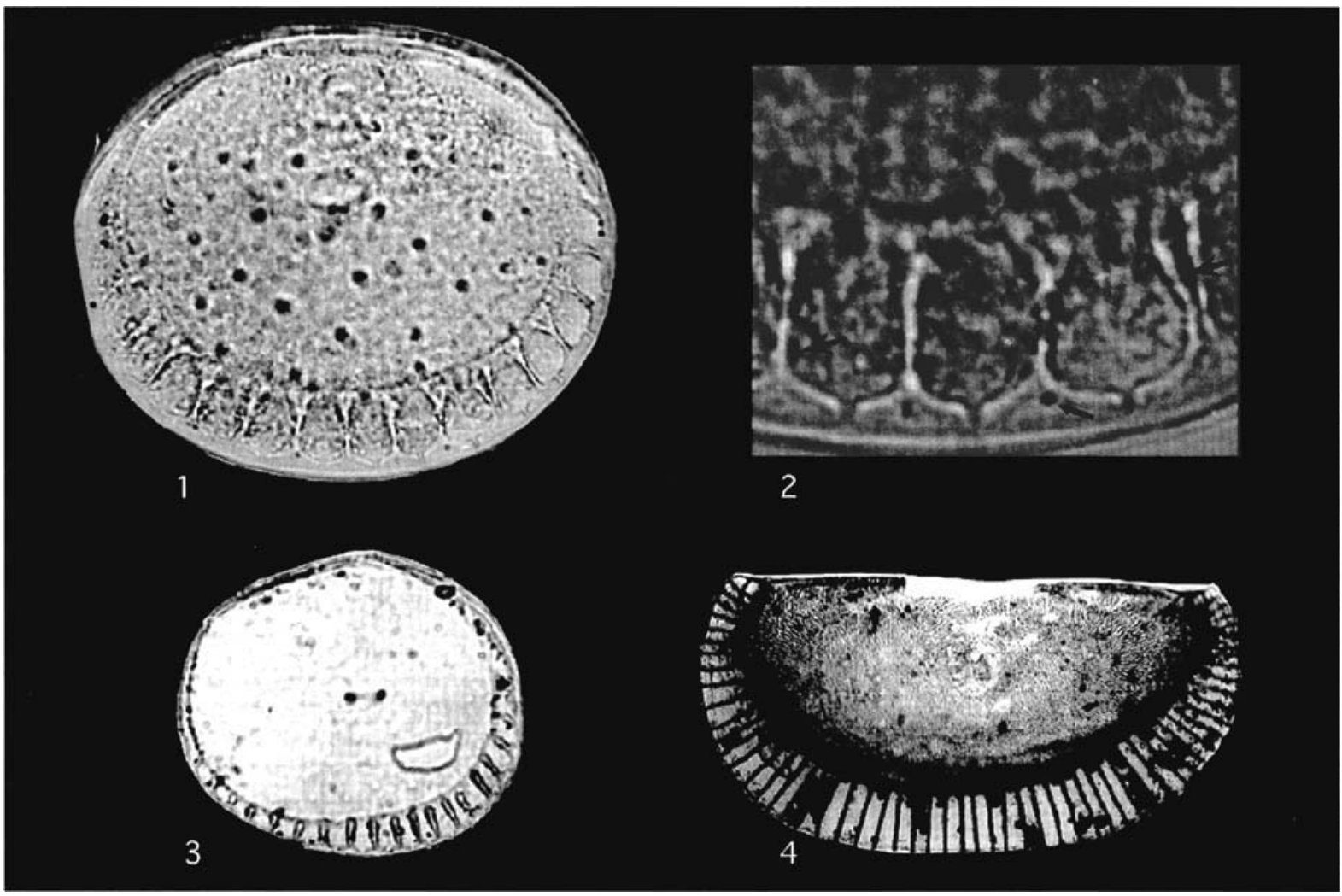

Fig. 2. Transmitted light photographs. figs 1-2. Axelheibergella arctica gen. et sp. nov. Paratype, RV A: fig. 1. interior lateral view, $\times 348$, fig. 2. detail of septa, larger arrows point to larger-diameter openings, and smaller arrow points to smaller diameter opening in the outer lamella of the axial zone, X858, GSC 115785; fig. 3. Axelheibergella punctata gen. et sp. nov. Paratype, RV A, exterior lateral view (a rectangular-shaped hole occurs in the shell), $\times 220$, GSC 115793; locality: Axel Heiberg, AH 87200-009, $1150 \mathrm{~m}$ PDWD. fig. 4. Puncia sp. B (60 camerae are present, but this species (although the specimen is missing part of its shell dorsally) lacks the two subdorsal ponticulate carinae of Puncia sp. A; the black areas of the camerae are entrapped air bubbles in the oil of cloves), RV A, exterior lateral view, $\times 97$, IGNS OP1156, Shakespeare Cliff Siltstone, Wanganui Coastal Section, North Island, New Zealand; New Zealand Metric Fossil Record File number R22/f6627 (1965 original collection), Pleistocene.

present in cladocopids, the author uses the term 'rostral incisure' to indicate a barely perceptible inflection in the curvature of the outline of the shell margin which helps to identify the anterior end of the shell from the posterior end. Shell and valve are used interchangeably throughout the text.

RV and LV refer to right and left valves, respectively. Measurements were made with an eyepiece micrometer grad- uated in units of $20 \mu \mathrm{m}$ at a magnification of $\times 80$. All dimensions are maximum ones and are given as length (L) $\times$ height $(\mathrm{H})$ in millimetres. A- 1 and A-2 refer to penultimate and antepenultimate instars, respectively. Specimen counts (Table 1) include valves and carapaces of adult and juvenile instars. By convention, one disarticulated valve or one articulated (bivalve) carapace counts as one specimen.

\section{Explanation of Plate 1}

Fig. 1. Reflected light photograph. Figs 2-13. Scanning electron microscope photographs. Figs 1-5, 7-11. Axelheibergella arctica gen. et sp. nov.: fig. 1, Holotype, RV A, exterior lateral view, $\times 207$, GSC 115780; fig. 2, Paratype, RV A, exterior lateral view, $\times 211$, GSC 115781 ; figs 3, 7-8, Paratype, LV A: fig. 3, interior lateral view, $\times 211$, fig. 7, detail of hinge, $\times 558$, fig. 8, detail of muscle scars, $\times 2160$, GSC 115782 ; figs 4, 9-11, RV A: fig. 4, interior lateral view of broken specimen (arrow points to nick point in section of shell shown in fig. 9), $\times 238$, fig. 9, detail of infold of ventral margin of specimen shown in fig. 4 (arrow points to enlargement of shell wall shown in fig. 11), $\times 895$, fig. 10, detail or posterior hinge of specimen shown in fig. 4, $\times 1018$, fig. 11, ultrastructure of outer lamella showing the two layers of endocuticle of specimen shown in fig. 4. Note the hummocky inner surface of the outer layer of the shell. The inner surface of the shell is shown top right and a sliver of the outer surface is visible in bottom right half of photograph, $\times 5200$, GSC 115783; fig. 5, LV A, interior lateral view of broken specimen exposing two cameral septa between outer lamella and broken away part of infold, $\times 235$, GSC 115784; locality: Axel Heiberg, AH 87200-009, $1150 \mathrm{~m}$ PDWD. Figs 6, 12. Axelheibergella punctata gen. et sp. nov.: fig. 6, Holotype, LV-A, exterior lateral view, $\times 232$, GSC 115791 ; fig. 12, LV-A, interior lateral view, detail of septa of an incompletely calcified adult shell (arrows point to two smaller-diameter pores in the outer lamella of the axial zone), $\times 353$. Note the interior expression of the puncta of this species, which indicates that calcification of the shell ceased shortly after the protoostracum stage in this specimen. GSC 115792; locality: Alpha Ridge, CESAR 83-211, $1730 \mathrm{~m}$ PDWD. Fig. 13. Puncia sp. A (possibly Puncia sp. A of Swanson (1991) with $c$. 60 camerae and two subdorsal ponticulate carinae), RV A, exterior lateral view, $\times 84$, IGNS OP1157, Tainui Shellbed, Wanganui Coastal Section, North Island, New Zealand; New Zealand Metric Fossil Record File number R22/f6628 (1970 recollection), Pleistocene. 
The illustrations of the microfossils were produced by digital imagery techniques (Scott, 1995). SEM and light microscope photographs were first made on glossy bromide paper, using conventional photographic methods. Each photograph was subsequently scanned at a resolution of $320 \mathrm{dpi}$ and imported into Adobe Photoshop, where the images were enhanced and rearranged to compose Plate 1 and Fig. 2, and the files saved in RGB format. A Fujix Pictrography 3000 colour printer was used with the same software to produce the black and white photographs (by the mixing of colours) at a resolution of 320 dpi on glossy paper. All of the digital imagery was done on a Macintosh platform.

\section{TERMINOLOGY AND DISCUSSION OF FUNCTIONAL MORPHOLOGY}

\section{Septa and camerae}

The presence of septa between infold and outer lamella along the free margin of four species of cladocopids is a radical departure from the conservative nature of the shell architecture in the order. This is particularly demonstrable in the polycopaceans, for example, in which the dome-shaped architecture of the shell exhibits perhaps the simplest known type of carapace design, as exemplified in Metapolycope by Benson (1981). Presumably the septa present in Axelheibergella act as buttresses which give added strength to the thinly calcified and fragile carapace along its periphery.

Camerae (camera, sing., cameral, adj.) are defined herein as the interseptal chambers that result from the formation of septa between outer lamella and infold along the free margin of each valve. Camerae are much wider structures than the combined widths of the adjacent radial septa that form their sides. The camerae in the two Arctic species of Axelheibergella are open to the interior of the valve cavity proximally (Pl. 1, figs 1, 3-5, 9, 12; Fig. 2, figs 1-3) and open to the exterior environment distally (Fig. 2, figs 1-3). Camerae are the morphological equivalent of the interseptal 'chambers' and the 'chamberlets' or 'compartments' used by Hornibrook $(1949,1963)$ to describe the interseptal areas of the punciid frill (Pl. 1, fig. 13; Fig. 2, fig. 4), and of the 'lunettes' used to describe the interseptal areas in the frill of Manawa by McKenzie \& Neil (1983). The 'hollow' in the frill of Promanawa between the 'radial canals' described by McKenzie \& Neil (1983) is apparently a camera.

The septa in the relatively wide axial plane between shell infold and outer lamella along the free margin of the shell of Axelheibergella are unique to this genus among the cladocopid ostracods. They are absent in myodocopids, podocopid platycopines, and in nearly all other podocopids, except for the freshwater cypridacean genera Stenocypris (Triebel, 1953, 1958; McKenzie, 1977), Strandesia (Triebel, 1958), Heterocypris (Triebel, 1953), Cypretta (Müller, 1894; Pokorný, 1965; McKenzie, 1977), and Bradycypris and Paracypretta (McKenzie, 1977). These freshwater genera show varying degrees of septal development in the area of the free-margin infold, with the septa particularly well-developed along the anterior and anteroventral margins of Cypretta, Heterocypris and Stenocypris. In some taxa, the septa are confined to one valve only (e.g. McKenzie, 1977).

The camerae of Axelheibergella, like the cameral structures of the marginally septate cypridacean podocopids listed above, could be the conduits through which epidermal cells and sensory cells (sensilla) are extended to the proximity of the outer shell margin, where the setae egress the shell through relatively short canals and marginal pores. It has also been suggested that the camerae and septa are in some way connected to the presence of the so-called marginal shell glands described in some polycopids. Marginal shell glands and their associated canals and pores will be discussed in greater detail below.

Septa are present in the enigmatic and extant Superfamily Punciacea Hornibrook, 1949. This taxon has been regarded as a wayward orphan by ostracod taxonomists, following description of Puncia and Manawa by Hornibrook (1949) and Promanawa by McKenzie \& Neil (1983): first, having been regarded as a palaeocopid and, then, as podocopid (podocopine or platycopine, or something intermediate between these two suborders). Although the debate continues, current opinion has come full circle and the Punciacea are once again regarded as the only living representatives of the predominately Palaeozoic Order Palaeocopida, but the relationship of this superfamily to the extinct Superfamily Kirkbyacea remains a subject of vigorous debate (e.g. Becker \& Swanson, 1992). Swanson (1985) pointed out that the septa in the punciid frill (Fig. 2, fig. 4) which were identified correctly by Hornibrook (1949) have subsequently been referred to incorrectly as marginal pore canals. The camerae in the frill of Puncia and Promanawa are normally closed distally, and Swanson (1991) attributes the cause of partially open to fully open camerae in some specimens of Puncia to incomplete calcification of the frill. Some of the camerae in the specimen of Puncia shown on Pl.1, fig. 13 are also open distally. Moreover, there is evidence to suggest that the camerae are closed off from the carapace interior (domicilium) proximally by a thin calcareous membrane (Swanson, 1985, 1991).

\section{Functional morphology of the septate punciid frill}

It has been suggested by Swanson (1991) that the septate punciid frill (Pl. 1, fig. 13; Fig. 2, fig. 4) may serve a dual role, functioning both as benthic support structure and gas-filled buoyancy device in Puncia and Promanawa; but, as Swanson pointed out, the true function of this structure must await the discovery of live specimens of these genera.

Swanson (1989a, b, 1991) observed live specimens of Manawa staceyi in the laboratory and found this punciid's ontogeny to be unique amongst all known living ostracods. In this species, the earliest juveniles were found to have single, dome-shaped (univalve) carapaces, whilst older juveniles and adults have bivalve carapaces, in which the valves of their instars are fully extended laterally to nearly $180^{\circ}$ during locomotion. If Puncia and Promanawa eventually turn out to share with Manawa the same, radically different lifestyle, it is entirely plausible that the punciid frill may have been an early evolutionary innovation in the palaeocopids of a structure analogous to alae in podocopids. The hydrodynamic cross-sectional shape of the frill of Puncia, for example, with its curved sole, is ideally suited for the ease of movement of a wide-gaped, thinly-calcified, delicate carapace either over or within the coarse biogenic sands (as described for Manawa), depending on whether species of the genus are epifaunal or infaunal, respectively. 


\section{Marginal pore canals, pores and setae}

A detailed histological and morphological study by Okada (1982) of normal and marginal pores bearing setae (sensillum pores) using light, scanning and transmission microscopy techniques has shown that, except for the canals being narrower and longer, marginal pores have an internal morphology essentially the same as normal pores.

Information on marginal (radial) pore canals and marginal pores in cladocopids is scarce and often contradictory. According to Hartmann (1955), Van Morkhoven (1963) and Pokorny (1965), sensillum-type marginal pores, as defined by Okada (1983), and their attendant canals are present in polycopids, but their numbers are few, and not much is known about them in detail. Hartmann $(1963,1965,1975)$ subsequently rejected the existence of sensillum-type marginal canals in polycopids, noting instead that the marginal canals and/or marginal pores present in some species of Polycope, e.g. Hartmann (1954, 1955), are associated with the marginal shell glands. In a comprehensive treatment on the classification of ostracods by Hartmann \& Puri (1974), there was no mention of the presence in cladocopids of normal or marginal pore canals, including those tied to shell glands.

Marginal setae or hair presumably associated with marginal pore canals have been reported by Hartmann $(1954,1955)$ from several species of Polycope he described from the Amphioxussands, near Banyuls-Sur-Mer, Mediterranean France, in 1954. In $P$. limbata and $P$. microdispar, setae are located on anterior and posteroventral margins, respectively, while in $P$. cancellea they are mostly confined to the hinge area. Unequivocal marginal pore canals (randständige Porenkänale) with setae were found by Hartmann (1959) in the infold of the attached margin of Polycope duplidentata Hartmann, 1959, where they are restricted to the area around the hinge bar. Kornicker \& Van Morkhoven (1976) do not discuss marginal pore canals per se in their treatment of Metapolycope, but they do, however, illustrate simple and noded pores along the valve edge of three species of Metapolycope that may be marginal pores. Moreover, Benson (1981) illustrated (his Fig. 3B) a marginal pore canal containing a seta in $M$. hartmanni, but Benson's Fig. 3D showing a marginal pore and seta appears to be the same as one he used earlier (Benson, 1975), which is an adaptation of a figure used by Kesling (1951) to show the shell morphology of Cypridopsis. Kornicker \& Iliffe (1989) illustrate several hairs on the anterodorsal margin of Polycopissa anax which exit through pores on the exterior (outer lamella) surface of the shell. Most of these hairs, however, are located within inner and outer shell margins, i.e. in the axial zone, the area of the shell between the infold and the outer lamella. The few marginal pore canals present in the infold along both free margin and attached margin areas are connected to shell glands, and some of these canals exit to the outer lamella shell surface short of the outer margin, while the remaining ones traverse the axial zone. The slender, shortcropped and closely spaced hairs that adorn the anteroventral, ventral and posteroventral margins of this species are attached to the selvage, and they appear to be non-sensory in function.

K. M. Swanson and S. H. Eagar have each shown the author scanning electron microscope (SEM) photographs of a modern species of Polycope and one of the myodocopid Ancohenia, respectively, from New Zealand, which clearly show setae present along the free margin of these taxa.

\section{Shell (exocrine) glands, shell gland canals and ducts}

Marginal shell glands, the function of which is unclear, and marginal canals presumably occupied by these glands (Kanäle der Schalenranddrüsen) are present in some species of Polycope, as reported by Hartmann (1954, 1955, 1963, 1965). Shell glands are present in Polycope onkophora Hartmann, 1954, and Hartmann (1954) described and illustrated structures in the infold area of the left valve of Polycope longipes Hartmann, 1954, which he referred to as marginal shell gland canals. The marginal structures illustrated in $P$. longipes by Hartmann (1954) are the septal and cameral structures described herein for Axelheibergella. Subsequently, Hartmann (1955) described and illustrated shell glands with nucleated cells that penetrate the axial zone of the infold of $P$. cancellea Hartmann, 1954, as seen in an oblique section through the (uncalcified?) shell margin. However, Hartmann (1955) acknowledged that the relationship between shell glands and the presumed canals and pores associated with them is anything but clear.

Chavtur (1981) transferred Hartmann's (1954) two species Polycope onkophora and P. longipes to Eupolycope Chavtur, 1981 and Polycopiella Chavtur, 1981, respectively, retaining only Hartmann's (1954) Polycope cancellea in Polycope.

Kornicker \& Iliffe (1989) illustrated shell glands ('glandular masses') between shell outer lamella and vestment of Polycopissa anax Kornicker \& Iliffe. The shell (exocrine) glands are largely concentrated along the inner margin of the infold, and most have canals that open through presumed exocrine pores on the outer surface of the shell as normal pore canals. However, a few of the canals that begin in the axial zone near the inner margin open to presumed exocrine pores on the outer surface of the shell within the axial zone, while fewer still pass through the axial zone to the valve margin. Two of the latter canals open to exocrine pores containing extrusions of an unspecified substance, with one of the extrusions partly coiled. According to Kornicker \& Iliffe (1989), the extruded substance is never present on the outer surface of the shell, where many of the shell gland (exocrine) pores are located.

Another important feature of exocrine pores that open on the outer lamella of the shell of cladocopids is the apparent lack of the finger-like (core-catcher like) projections that surround and sometimes cover the opening in cytheracean podocopids, as shown by Okada $(1982,1983)$ and Hanai (1988).

Shell glands are very common along the free margin in the non-calcified to slightly calcified shells of the mostly pelagic halocypridacean myodocopids. Some glands open into a common pore along the free margin, as shown by Müller (1894, 1908, 1912) and Skogsberg (1920), and especially in Alacia belgicae (Müller, 1906), as shown by Kock (1992), but the real function of the marginal shell glands in this superfamily and, by implication, in cladocopids, is not known, according to a summary and discussion of these glands by Hartmann (1955) of past theories on their functional use.

\section{Conclusion}

More research on the nature and extent of sensilla and exocrine types of marginal pore canals in cladocopids is needed, but the limited data available indicate the presence of one or the other 
or both types of pore canals in some taxa, although these structures are not known in any great detail. Furthermore, the sensilla-type pores of cladocopids may not serve the same function as those present in podocopids (K. M. Swanson, written comm.).

There is ample evidence to suggest that shell glands, particularly the marginal type of gland, do not occur uncommonly in cladocopid ostracods, based on Hartmann's (1954, 1955) and Kornicker \& Iliffe's (1989) studies. There is no evidence, however, to suggest that the septa and camerae present in the axial zone of the infold of Axelheibergella are a consequence of these marginal shell glands.

\section{SHELL ULTRASTRUCTURE}

The shell ultrastructure of Polycope and Metapolycope was investigated by Sohn \& Kornicker (1988). In both genera the endocuticle is formed of a relatively thick outer fine granular layer capped on its exterior side by a thin epicuticle layer, and a thinner inner columnar layer. The epicuticle is the outermost cuticular layer of the ostracod exoskeleton that does not become calcified. It is the template on which calcification of the endocuticle layer of the shell first takes place, and the finest of ornamental structures of the epicuticle such as puncta and foveolae are replicated in this incipient stage of shell calcification. I have referred to this first-formed and thus outermost mineralized layer of the ostracod shell as the protoostracum and this first step of mineralization of the cuticle the protoostracum stage of shell calcification. Sohn \& Kornicker (1988) have shown the relationship between puncta in the epicuticle and the underlying calcified endocuticle in an unnamed species of Polycope. This relationship is also shown in $\mathrm{Pl}$. 1, fig. 12 of the inner side of a fragment of the shell of Axelheibergella punctata, where the convex surfaces of numerous puncta are visible. The photograph also shows that shell calcification advanced very little beyond the protoostracum stage before the ostracod died, and that the wide infold and septa were in place at this earliest stage of shell calcification.

The broken shell of Axelheibergella arctica shown on Pl. 1, fig. 4 consists of two distinct layers, which are shown in greater detail in oblique views of the shell on Pl. 1, figs 9-11. The two layers shown in the broken section of the shell running from the dorsum to the venter are of about equal thickness, but their ultrastructure appears to be quite different. The separation of the shell into two layers may be due to weak bonding between two layers differing slightly in composition, and it probably occurred contemporaneously with, and as a result of, the breakage of the shell. The epicuticle layer is not discernible in the outer shell layer of the section. Because the two layers are nearly equal in thickness, they are assumed to be the endocuticle component of the shell, exclusive of any epicuticle layer that may be present in the outermost layer. Slightly below midheight and near the nick point caused by the offset of the outer shell layer across a small break that affects this layer only (arrow, Pl. 1, figs 4,9), the combined thicknesses of the layers of the shell wall are c. $3.7 \mu \mathrm{m}$ (Pl. 1, fig.11). The outer of the two layers (Pl. 1, fig.11) is fine granular, relative to the coarse granular nature of the inner layer. Both layers in this region of the shell have a weak but nevertheless discernible columnar (linear) component. Moreover, the inner, lateral surface of the outer shell layer (Pl. 1, fig. 4) exposed by the breakage has a hummocky topography (Pl. 1 , fig. 11). Ventrally, the two endocuticle layers continue to the shell margin, but they then merge to become one layer along the less thick infolded part of the shell wall, which appears to be finely laminated (Pl. 1, fig. 9). Dorsally, in the region of the infolded part of the shell that forms the hinge, the integrity of the two endocuticle layers is maintained and both are distinctly laminated (Pl. 1, fig. 10). Dissolution and attendant differential etching of the endocuticle and the exposure of its organic matrix has occurred in the shell possibly prior to, and certainly following, the major break in the shell wall, greatly enhancing detection of the endocuticle laminae and their geometry. I have used the effects of naturally occurring dissolution and breaks in the ostracod shell to full advantage in studies of the ultrastructure of hemicytherid and trachyleberidid cytheracean podocopids from New Zealand.

The ultrastructure of the shell of Axelheibergella differs in several ways from the ultrastructure of Polycope and Metapolycope. The laminate ultrastructure of the endocuticle in the infold of Axelheibergella is apparently absent in the infold of Polycope and Metapolycope, and perhaps in other cladocopid genera. It is most like that described in the infold of some myodocopid genera. Additional studies need to be carried out on cladocopid ultrastructure before any significance can be attached to the laminate nature of the infold of Axelheibergella.

\section{SYSTEMATIC DESCRIPTIONS \\ Phylum Crustacea Pennant, 1777 \\ Class Ostracoda Latreille, 1806 \\ Order Cladocopida Sars, 1866}

Remarks. Ostracod classification at the ordinal level and above is in a state of flux. Kornicker \& Iliffe (1989) recognize the Superorder Myodocopa Sars, 1866, which contains the orders Myodocopida Sars and Halocyprida Dana, 1853. The Halocyprida comprise the suborders Halocypridina Dana and the Cladocopina, Sars, 1866. In this paper, and for convenience only, I regard the Cladocopida and Myodocopida as orders, and the halocyprids are given family-group status within the Myodocopida.

Suborder Cladocopina Sars, 1866

Superfamily Polycopacea Sars, 1866

Family Polycopidae Sars, 1866

Remarks. As understood herein, the Polycopidae comprise 17 living genera distributed amongst two subfamilies: Polycopinae Sars, 1866 (15) and Polycopsisinae Chavtur, 1981 (2).

\section{Genus Axelheibergella nov.}

Type species. Axelheibergella arctica sp. nov.

Derivation of name. Axel Heiberg Island, Canadian Arctic Archipelago.

Diagnosis. Small ( $\mathrm{L} \leq 320 \mu \mathrm{m}$ ), subcircular to subelliptical lateral-outline cladocopids with a well-developed, free-margin infold, with axial zone between infold and outer lamella containing up to 20 or more radially aligned septa and interseptal chambers (camerae) open to the interior of the shell proximally, and to the exterior of the shell marginally.

Stratigraphic range. Quaternary.

Remarks. The genus at present contains the two species 
described in this report from the CAO and two species from the Mediterranean Sea. The Mediterranean Sea species include Polycope longipes Hartmann (Hartmann, 1954, p. 91, pl.30, figs 6a-f; pl. 34, figs $6 \mathrm{~g}-\mathrm{i}$ ), based on three specimens from Amphioxus-Sands near Banyuls, Gulf of Lion, southern France, and Polycope sp. B, from the Limski Channel, Adriatic Sea, described from seven specimens by Uffenorde $(1972$, p. 50, pl. 1, fig. 3). The Gulf of Lion and the Adriatic Sea species are larger ( 320 and $230 \mu \mathrm{m} \mathrm{L}$, respectively) than the two CAO species $(200 \mu \mathrm{m} \mathrm{L})$. The two CAO species of Axelheibergella are amongst the smallest of the 71 modern cladocopids ranked by length size by Neale (1983). The Mediterranean species also differ from the CAO species by having an infold containing more than 20 septa. Hartmann (1954), as noted above, referred to the septa as canals opening from glands in the proximity of the shell margin, while Uffenorde (1972) simply referred to them as cone shaped structures.

Septa are present in the earliest instars of both Arctic Ocean species of Axelheibergella, based on an examination of the juveniles in the more than 3000 specimens of the two species in the AOS'94 box cores from the Amerasian Basin.

The soft-part anatomy of Polycope longipes was described by Hartmann (1954). Chavtur (1981) included this species and several others in the genus Polycopiella which was established at the same time.

No details of the ecology of Polycope longipes were given by Hartmann (1954). Uffenorde (1972) reported Polycope sp. B from five stations in the Limski Channel, in water depths between 32 and $37 \mathrm{~m}$, bottom temperatures between 13 and $20^{\circ} \mathrm{C}$, and salinity of c. $38 \%$.

Axelheibergella arctica sp. nov.

(Pl. 1, figs 1-5, 7-11; Fig. 2, figs 1-2)

Derivation of name. With reference to the geographic locale of this taxon, the Arctic Ocean.

Diagnosis. Carapace small, nearly circular in lateral outline, surface smooth except for faint pattern of punctate, mostly zigzag furrows arranged in two to three poorly defined concentric ellipses; $25-30$ widely spaced normal pores; about 17 free-margin septa.

Holotype. RV A GSC 115780.

Material. Fifteen adult valves, nine entire, six broken. In addition, one LV adult specimen was lost from the tip of the picking brush during transfer to a single-cell cavity slide, and one RV A-1 or A-2 juvenile disintegrated during manipulation with the picking brush; both specimens were from Axel Heiberg locality AH 872000-009.

Locality and horizon. Axel Heiberg upper slope, CAO. Locality AH $87200-009$, Lat. $82^{\circ} 09.62^{\prime} \mathrm{N}$; Long. $102^{\circ} 33.87^{\prime} \mathrm{W}$. DietzLaFond grab, top 0-1 cm, $1150 \mathrm{~m}$ PDWD. Holocene. Present also at Alpha Ridge, CAO. CESAR locality 83-211, Lat. $85^{\circ} 43.9^{\prime} \mathrm{N}$; Long. $108^{\circ} 51.9^{\prime} \mathrm{W}$. Gravity core, top $0-1 \mathrm{~cm}$, $1730 \mathrm{~m}$ PDWD. Holocene.

Description. Carapace small ( $\mathrm{L} \leq 200 \mu \mathrm{m})$, nearly circular in lateral outline; rostral incisure barely perceptible; dorsum of right valve slightly deflated laterally along attached margin. Lateral surface nearly smooth except for faint, zigzag pattern of punctate shallow furrows arranged in two to three poorly defined concentric ellipses; normal pores widely spaced, scattered, about $25-30$ in number, with one centrally located pore containing two ducts ( $\mathrm{Pl}$. 1, fig. 2: centre white spot). Narrow flange surrounds most of free margin; the outer lamella shell margin adjacent to flange is fluted (scallop shaped), particularly along anterior and anteroventral margins. Crests are present between adjacent flutes. Internally, infold well developed, relatively wide ventrally, tapering gradually toward free-margin extremities (Pl. 1, figs 1, 3-5); septa radially aligned, double-walled, hairpin-shaped structures, with bend of hairpin coincident with inner margin of infold proximally, and with each leg of the hairpin structure bending away from fold axis distally to form, overall, about 17 inverted $\mathrm{Y}$-shaped septal structures (Pl. 1, fig. 1; Fig. 2, figs 1-2); interseptal chambers (camerae) arched distally, arch formed of adjacent bent legs of Y-shaped septal structures; camerae open to shell interior proximally, and to shell exterior distally through much smaller diameter opening; each opening leading to canal opening to outside through crest (?) between adjacent flutes. Posterior-most and ventral scar of three adductor scars wedge-shape (Pl. 1, fig. 8), with thin edge of scar directed anteriorly, upper two scars polygonal. Attached margin depressed below dorsum; hinge element of left valve (Pl. 1, fig. 7) the sloped edge of the attached margin infold which fits into a well-defined groove in the infold of the attached margin of the right valve (Pl. 1, fig. 4). Sexual dimorphism not observed. Dimensions (mm).

Holotype: RV A GSC 115780 Locality AH 87200-009 $\quad \begin{array}{cc}\text { L } & \text { H } \\ 0.19 \times 0.17 & \end{array}$ Paratype: RV A GSC 115781 Locality AH 87200-009 $0.20 \times 0.16$ Paratype: LV A GSC 115782 Locality AH 87200-009 $0.20 \times 0.16$ Paratype: RV A GSC 115785 Locality AH 87200-009 $0.20 \times 0.17$ Paratype: RV A GSC 115786 Locality AH 87200-009 $0.19 \times 0.16$ Paratype: RV A GSC 115787 Locality AH 87200-009 $0.20 \times 0.17$ Paratype: RV A GSC 115788 Locality AH 87200-009 $0.19 \times 0.16$ Paratype: RV A GSC 115789 Locality AH 87200-009 $0.19 \times 0.16$ Paratype: RV A GSC 115790 Locality CESAR 83-211 $0.20 \times 0.16$ Remarks. Other openings of canals that lead to the outer or external surface of the shell are present in the axial zone between shell outer lamella and infold in this species (arrow, Pl. 1, fig. 5; larger arrows Fig. 2, fig. 2). These openings are of similar size to the normal pores scattered over the valve, as described above. They are also similar to openings described by Kornicker \& Iliffe (1989) in the axial zone of the shell of Polycopissa anax, a species containing numerous shell glands. According to Kornicker \& Iliffe (1989) the openings connect pore canals (? chitinous tubule extensions) leading from the glands, which are located between vestment and shell, to the outer surface of the shell by way of the axial zone. A third type of axial zone canal opening, with a smaller diameter than the ones described above, occurs at the distal end of some of the septa, within the inverted $\mathrm{Y}$-shaped area (smaller arrow, Fig. 2, fig. 2). The function of the canals leading from these openings to the outside of the shell is not known, nor is the geometry of the openings and their proximity to the septa understood.

One adult LV specimen of this species (dimensions, $\mathrm{mm}$ : $0.19 \times 0.18)$ is present in Arctic'91 Polarstern sample PS2186-5 (GKG), Lomonosov Ridge, $88^{\circ} 31.2^{\prime} \mathrm{N}, 140^{\circ} 9.6^{\prime} \mathrm{E}, 1996 \mathrm{~m}$ PDWD, in the interval $10-11 \mathrm{~cm}$ downcore (T. M. Cronin, pers. comm.). A lithological description of the box-core sediments is recorded in Fütterer (1992). 
Axelheibergella punctata sp. nov.

(Pl. 1, figs 6,12; Fig. 2, fig. 3)

Derivation of name. With reference to the punctate surface of this taxon.

Diagnosis. Carapace small, subelliptical in lateral outline; surface punctate; about 40 widely spaced normal pores; about 20 free-margin septa. Several saw-tooth denticles present along antero- and posteroventral margins.

Holotype. LV A GSC 115791.

Material. Six adult and juvenile valves, only four of which are unbroken.

Locality and horizon. Alpha Ridge, CAO, CESAR locality 83211, Lat. $85^{\circ} 43.9^{\prime} \mathrm{N}$; Long. $108^{\circ} 51.9^{\prime} \mathrm{W}$. Gravity core, top 0 $1 \mathrm{~cm}, 1730 \mathrm{~m}$ PDWD. Holocene. Present also on the Axel Heiberg upper slope, CAO. Locality AH 87200-009, Lat. $82^{\circ} 09.62^{\prime} \mathrm{N}$; Long. $102^{\circ} 33.87^{\prime} \mathrm{W}$. Dietz-LaFond grab, top 0 $1 \mathrm{~cm}, 1150 \mathrm{~m}$ PDWD. Holocene.

Description. Carapace small ( $\mathrm{L} \leq 200 \mu \mathrm{m}$ ), subelliptical in lateral outline, highest at anterior cardinal angle; rostral incisure slight; surface punctate except for a smooth, relatively narrow, continuous marginal strip, highly sinuous on its inner side, running from anterodorsal margin along dorsum to posteroventral margin, and a smooth circular area in centre of valve; about 40 widely spaced normal pores; about 20 free-margin septa. The same type of marginal flange and adjacent fluted structures present in the type-species are also present in this species. The crests between adjacent flutes appear to be aligned with the cameral openings present between the bent legs of adjacent double-walled septal elements. About 8-10 saw-tooth denticles are present along the anteroventral margin (P1. 1, fig. 12), with each denticle positioned opposite a cameral opening (Fig. 2, fig. 3). Although it is unclear, the canals leading from the cameral openings most likely open to the outside of the shell through the crests rather than through the denticles. Somewhat smaller and fewer denticles are present along the posteroventral margin.

Dimensions $(\mathrm{mm})$.

L $\quad \mathrm{H}$

Holotype: LV A GSC 115791 Locality CESAR 83-211 $0.20 \times 0.16$ Paratype: RV A GSC 115793 Locality AH 87200-009 $0.20 \times 0.17$ Paratype: RV A GSC 115794 Locality CESAR $83-211 \quad 0.19 \times 0.15$ Paratype: LV A-1 GSC 115795 Locality CESAR 83-211 $0.15 \times 0.13$

Remarks. The muscle scars, their arrangement and details of the hinge were not observed in this species. The configuration and arrangement of the septa and camerae are the same as described for A. arctica. Septa are Present in the A-1, possibly A-2, juvenile. Some of the larger diameter pores present in the outer lamella of the axial zone of the type-species are also present in this species (arrows, Pl. 1, fig. 12), but the smaller diameter pores present at the ends of the inverted $Y$-shaped septa in the typespecies were not observed. A surface pore similar in size and location to the two-duct pore of the type-species occurs in the centre of the smooth central area of the shell (P1. 1, fig. 6), but it appears to have one duct only.

\section{ACKNOWLEDGEMENTS}

I thank Peta J. Mudie, Steven M. Blasco and Iris A. Hardy, Geological Survey of Canada, Bedford Institute of Oceanogra- phy, for providing the samples and locality data. John Andrews, Donnie Barber, Wendy Cunningham, John Hollin, Rolf Kihl, Vera Markgraf, Mark Meier, Susan Short, Kerstin Williams (INSTAAR), Rich Harding (Molecular, Cellular and Developmental Biology), and Doug Wray (Engineering), all of the University of Colorado, provided various amenities, including supplies, use of equipment, services and encouragement. John Hollin, Nancy Weiner and Kerstin Williams offered suggestions on how to improve the manuscript. Thomas Cronin, U.S. Geological Survey, Reston, provided the Arctic'91 sample containing Axelheibergella arctica. Ursula Grigg and Qadeer Siddiqui, Saint Mary's University, Halifax and Elisabeth Brouwers, U.S. Geological Survey, Denver, provided copies of some of the more inaccessible references. Kjell Sandved, Smithsonian Institution, and Bob Grover, Grover Instruments Corporation, custom built the bellows camera stand and loaned the Zeiss Luminar lens, respectively. P.-N. Webb (Ohio State University) provided the SEM photograph of Puncia sp. A, while with the New Zealand Geological Survey, 1970. George Scott (Institute of Geological \& Nuclear Sciences, Ltd., New Zealand) and David Underwood (University of Colorado) provided advice and services, respectively, for the digital imagery techniques used to produce the illustrations. Christina Callicott, Teresa Nettleton, Nina Seevers and Travers Ichinose (University of Colorado) provided invaluable assistance in the processing of the AOS'94 box core samples.

All of the taxa illustrated in this report were presented at an informal talk given at the Friends of the Ostracodes meeting (predecessor of The North American Research Group on Ostracoda), 1 November 1989, at the Denver Annual Meeting of the Geological Society of America. I thank Jean Berdan, Smithsonian Institution, and R. Lundin, University of Arizona, for comments and a discussion of functional morphology following the presentation.

Finally, I thank Stephen Eagar, Victoria University of Wellington, and Kerry Swanson, University of Canterbury, Christchurch, New Zealand, for discussions via electronic mail of cladocopid, myodocopid and punciacopine morphology and taxonomy, and the exchange of scanning electron microscope photographs

Partial support for this project was provided by National Science Foundation (ARCSS/OPP) Grant No. OPP-9400255.

Manuscript received July 1993

Manuscript accepted November 1996

\section{REFERENCES}

Aagaard, K., Swift, J. H. \& Carmack, E. C. 1985. Thermohaline circulation in the Arctic Mediterranean Seas. Journal of Geophysical Research, 90: 4833-4846.

Aksu, A. E. 1985. Paleomagnetic stratigraphy of the CESAR cores. In Jackson, H. R., Mudie, P. J. \& Blasco, S. M. (Eds.) Initial geological report on CESAR - the Canadian Expedition to study the Alpha Ridge, Arctic Ocean. Geological Survey of Canada Paper 84-22: 101 114. Ottawa.

Aksu, A. E. \& Mudie, P. J. 1985. Magnetostratigraphy and palynology demonstrate at least 4 million years of Arctic Ocean sedimentation. Nature, 318: 280-283.

Becker, G. \& Swanson, K. M. 1992. Are the Kirkbyacea extinct palaeocopine ostracods or close relatives of the extant Punciacea? Senckenbergiana lethaea, 72: 121-128. 
Benson, R. H. 1975. Morphologic stability in Ostracoda. Bulletins of American Paleontology, 65: 13-46.

Benson, R. H. 1981. Form, function, and architecture of ostracode shells. Annual Review of Earth and Planetary Science 1981, 9: 59-80.

Beu, A. G. \& Edwards, A. R. 1984. New Zealand Pleistocene and late Pliocene glacio-eustatic cycles. Palaeogeography, Palaeoclimatology, Palaeoecology, 46: 119-142.

Beu, A. G., Edwards, A. R. \& Pillans, B. J. 1987. A review of New Zealand Pleistocene stratigraphy, with emphasis on the marine rocks. In Itihara, M. \& Kamei, T. (Eds.) Proceedings of the First International Colloquium on Quaternary Stratigraphy of Asia and Pacific Area, Osaka, 1986, 250-269. INQUA Commission on Quaternary Stratigraphy, Osaka.

Chavtur, V. G. 1981. On the systematic position of the modern Ostracoda in the Family Polycopidae (Ostracoda, Cladocopinae). Trudy Institute Okeanologiia, 115: 53-60 [In Russian].

Clark, D. L., Chern, L. A., Hogler, J. A., Mennicke, C. M. \& Atkins, E. D. 1990. Late Neogene climate evolution of the central Arctic Ocean. Marine Geology, 93: 69-94.

Clark, D. L., Whitman, R. R. \& Morgan, K. A. 1980. Stratigraphy and glacial-marine sediments of the Amerasian Basin, central Arctic Ocean. Geological Society of America, Special Paper 181, 57 pp. Boulder.

Clark, D. L., Andree, M., Broecker, W. S., Mix, A. C., Bonani, G., Hoffman, H. J., Morenzoni, E., Nessi, M., Suter, M. \& Woelfli, W. 1986. Arctic Ocean chronology confirmed by accelerator ${ }^{14} \mathrm{C}$ dating. Geophysical Research Letters, 13: 319-321.

Coachman, L. K. \& Aagaard, K. 1974. Physical oceanography of Arctic and subarctic seas. In Herman, Y. (Ed.) Marine Geology and Oceanography of the Arctic Seas, 1-72, Springer, New York.

Cronin, T. M., Holtz, T. R. Jr. \& Whatley, R. C. 1994. Quaternary paleoceanography of the deep Arctic Ocean based on quantitative analysis of Ostracoda. Marine Geology, 119: 305-332.

Cronin, T. M., Holtz, T. R. Jr., Stein, R., Spielhagen, R., Fütterer, D. \& Wollenburg, J. 1995. Late Quaternary paleoceanography of the Eurasian Basin, Arctic Ocean. Paleoceanography, 10: 259-281.

Finch, E. M. 1974. An improved method of mounting palaeontological specimens for SEM examination. Palaeontology, 17: 431-434.

Fütterer, D. K. 1992. (Ed.), Arctic'91: Die Expedition ARK-VIII/3 mit FS Polarstern 1991. Berichte zur Polarforschung, Bremerhaven, No. $107,1-267$.

Hanai, T. 1988. A taxonomist's view on classification. In Hanai, T., Ikeya, N. \& Ishizaki, K. (Eds.) Evolutionary Biology of Ostracoda, its Fundamentals and Applications, proceedings of the Ninth International Symposium on Ostracoda, held in Shizuoka, Japan, 29 July-2 August 1985. Developments in palaeontology and stratigraphy, 11, 17-26, Kodansha Ltd, Tokyo and Elsevier, Amsterdam.

Hartmann, G. 1954. Neue Polycopidae (Ostracoda: Cladocopa) von europäischen Küsten. Kieler Meeresforschungen, 10: 84-99.

Hartmann, G. 1955. Zur Morphologie der Polycopididen. Zeitschrift für Wissenschaftliche Zoologie, Abt. A, 157: 193-248.

Hartmann, G. 1959. Zur Kenntnis der lotischen Lebensbereiche der pazifischen Küste von El Salvador unter besonderer Berücksichtigung seiner Ostracodenfauna (III. Beitrag zur Fauna El Salvadors). Kieler Meeresforschungen, 15: 187--241.

Hartmann, G. 1963. Zur Phylogenie und Systematik der Ostracoden. Zeitschrift für Zoologie Systematik und Evolutionsforschung, 1: 1-154.

Hartmann, G. 1965. Neontological and paleontological classification of Ostracoda. Pubblicazioni della stazione zoologica di Napoli, Naples, 33 Suppl., (1964): 550-587.

Hartmann, G. 1975. Ostracoda. In Gruner, H.-E. (Ed.) Dr. H. G. Bronns Klassen und Ordnungen des Tierreichs. 5 Arthropoda, Abt. 1 Crustacea, Buch 2, Teil 4, Lieferung 4, 569-786. Gustav Fischer, Jena.

Hartmann, G. \& Puri, H. S. 1974. Summary of neontological and paleontological classification of Ostracoda. Mitteilungen aus dem Hamburgischen Zoologischen Museum und Institut, 70: 7-73.

Hornibrook, N. de B. 1949. A new family of living Ostracoda with striking resemblances to some Palaeozoic Beyrichidae. Transactions of the Royal Society of New Zealand, 77: 469-471.

Hornibrook, N. de B. 1963. The New Zealand ostracode family Punciidae. Micropaleontology, 9: 318-320.

Jackson, R. 1986. Ice island lab shows petroleum potential. Geos, 15: 1-
Jackson, R. \& Mudie, P. 1984. CESAR cores: geological time capsules. Geos, 13: 15-18.

Jackson, H. R., Mudie, P. J. \& Blasco, S. M. 1985 (Eds). Initial geological report on CESAR - The Canadian Expedition to Study the Alpha Ridge, Arctic Ocean. Geological Survey of Canada Paper 84-22, 177 p., Ottawa.

Joy, J. A. \& Clark, D. H. 1977. The distribution, ecology and systematics of the benthic Ostracoda of the central Arctic Ocean. Micropaleontology, 23: 129-154.

Kesling, R. V. 1951. The Morphology of Ostracod Molt Stages. Illinois Biological Monographs, 21(1-3), i-viii, 1-324. The University of Illinois Press, Urbana.

Kock, R. 1992. Ostracoden im Epipelagial vor der Antarktischen Halbinsel - ein Beitrag zur Systematik sowie zur Verbreitung und Populationsstruktur unter Berücksichtigung der Saisonalität. Berichte zur Polarforschung, Bremerhaven, No. 106, 1-209.

Kornicker, L. S. 1969. Relationship between the free and attached margins of the myodocopid ostracod shell. In Neale, J. W. (Ed.) Morphology and Ecology of Recent Ostracods, 109-135. Oliver \& Boyd, Edinburgh.

Kornicker, L. S. \& Iliffe, T. M. 1989. Ostracoda (Myodocopina, Cladocopina, Halocypridina) mainly from anchialine caves in Bermuda. Smithsonian Contributions to Zoology, Washington, No. $475,1-88$.

Kornicker, L. S. \& Van Morkhoven, F. P. C. M. 1976. Metapolycope, a new genus of bathyal Ostracoda from the Atlantic (Suborder Cladcopida). Smithsonian Contributions to Zoology, Washington, No. 225, 1-29.

McKenzie, K. G. 1977. Illustrated generic key to South African continental Ostracoda. Annals of the South African Museum, 74: 45103.

McKenzie, K. G. \& Neil, J. V. 1983. Promanawa, gen. nov., an Australian Miocene punciid ostracode from Hamilton, Victoria. Proceedings of the Royal Society of Victoria, 95: 59-64.

Morris, T. H. 1988. Stable isotope stratigraphy of the Arctic Ocean: Fram Strait to central Arctic. Palaeogeography, Palaeoclimatology, Palaeoecology, 64: 201-219.

Müller, G. W. 1894. Die Ostracoden des Golfes von Neapel und der angrenzenden Meeres-Abschnitte. In Fauna und Flora des Golfes von Neapel und der Angrenzenden Meeres-Abschnitte, 21, 1-104. Berlin.

Müller, G. W. 1908. Die Ostracoden der Deutschen Südpolar-Expedition 1901-1903. Deutsche Südpolar-Expedition 1901-1903, 10(2) [Zoologie 2(2)], 51-182. Berlin.

Müller, G. W. 1912. Ostracoda. In Schulze, F. E. (Ed.), Das Tierreich, Lieferung 31, 1-434. R. Friedländer und Sohn, Berlin.

Mungall, C. 1984. Floating islands of ice. Geos, 13: 1-2.

Neale, J. W. 1983. Geological history of the Cladocopina. In Maddocks, R. F., (Ed.), Applications of Ostracoda, 612-626. University of Houston.

Okada, Y. 1982. Ultrastructure and pattern of the carapace of Bicornucythere bisaensis (Ostracoda, Crustacea). In Hanai, T. (Ed.) Studies on Japanese Ostracoda, 229-267. University Museum, University of Tokyo, Bulletin 20.

Okada, Y. 1983. Ultrastructure and functions of pores of ostracodes. In Maddocks, R. F., (Ed.) Applications of Ostracoda, 640-648. University of Houston.

Pak, D. L., Clark, D. L. \& Blasco, S. M. 1992. Late Pleistocene stratigraphy and micropaleontology of a part of the Eurasian Basin (= Fram Basin), central Arctic Ocean. Marine Micropaleontology, 20: $1-22$.

Pokorny, V. 1965. Principles of Zoological Micropalaeontology, 2, Neale, J. W. (Ed.) 465 p. Pergamon Press, Oxford.

Schröder-Adams, C. J., Cole, F. E., Medioli, F. S., Mudie, P. J., Scott, D. B. \& Dobbin, L. 1990a. Recent Arctic shelf foraminifera: seasonally ice covered vs. perennially ice covered areas. Journal of Foraminiferal Research, 20: 8-36.

Schröder-Adams, C. J., Mudie, P. J., Cole, F. E. \& Medioli, F. S. 1990b. Late Holocene benthic foraminifera beneath perennial sea ice on an Arctic continental shelf. Marine Geology, 93: 225-242.

Scott, D. B., Mudie, P. J., Baki, V., Mackinnon, K. D. \& Cole, F. E. 1989. Biostratigraphy and late Cenozoic paleoceanography of the 
Arctic Ocean: foraminiferal, lithostratigraphic, and isotopic evidence. Geological Society of America Bulletin, 101: 260-277.

Scott, G. 1995. Digital imagery for making plates. Journal of Micropalaentology, 14: 118 .

Skogsberg, T. 1920. Studies on marine Ostracoda. Pt.1. (cyprinids, halocyprids, and polycopids). Zoologische Beiträge aus Uppsala, 1 (Suppl.): 1-787. Stockholm.

Sohn, I. G. \& Kornicker, L. S. 1988. Ultrastructure of myodocopid shells (Ostracoda). In Hanai, T., Ikeya, N. \& Ishizaki, K. (Eds.), Evolutionary Biology of Ostracoda, 243-258. Kodansha Ltd., Tokyo.

Swanson, K. M. 1985. The discovery of living punciid ostracodes in New Zealand. New Zealand Geological Survey Record, 9: 87-89. Lower Hutt.

Swanson, K. M. 1989a. Ostracod phylogeny and evolution - a manawan perspective. Courier Forschungsinstitut Senckenberg, 113: 11-20.

Swanson, K. M. 1989b. Manawa staceyi n. sp. (Punciidae, Ostracoda): soft anatomy and ontogeny. Courier Forschungsinstitut Senckenberg, 113: $235-249$.

Swanson, K. M. 1991. Distribution, affinities and origin of the Punciidae (Crustacea: Ostracoda). Memoirs of the Queensland Museum, 31: 7792.

Triebel, E. 1953. Genotypus und Schalen-Merkmale der OstracodenGattung Stenocypris. Senckenbergiana, 34: 5-14.
Triebel, E. 1958. Spezielle Arbeitsgebiete der Mikropaläontologie 2. Ostracoden. In Freund, H. (Ed.) Handbuch der Mikroskopie in der Technik, 8: 193-236. Umschau Verlag, Frankfurt.

Uffenorde, H. 1972. Ökologie und jahreszeitliche Verteilung rezenter benthonischer Ostracoden des Limski Kanal bei Rovinj (nördliche Adria). Góttinger Arbeiten zur Geologie und Paläontologie, 13: 1-121.

Van Morkhoven, F. P. C. M. 1962. Post-Palaeozoic Ostracoda, their Morphology, Taxonomy, and Economic Use, 1, 204 pp. Elsevier, Amsterdam.

Van Morkhoven, F. P. C. M. 1963. Post-Palaeozoic Ostracoda, their Morphology, Taxonomy, and Economic Use, 2, 478 pp. Elsevier, Amsterdam.

Van Wagoner, N. A., Mudie, P. J., Cole, F. E. \& Daborn, G. 1989 Siliceous sponge communities, biological zonation, and Recent sealevel change on the Arctic margin: Ice Island results. Canadian Journal of Earth Science, 26: 2341-2355.

Whatley, R. \& Eynon, M. P. 1996. Four new Arctic deepwater ostracod species from East Greenland. In Keen, M. C. (Ed.) Proceedings of the 2nd European Ostracodologists Meeting, University of Glasgow 1993, 195-200.

Witte, W. K. \& Kent, D. V. 1988. Revised magnetostratigraphies confirm low sedimentation rates in Arctic Ocean cores. Quaternary Research, 29: 43-53. 